MICROPALAEONTOLOGY NOTEBOOK

\title{
Resting stage in benthic foraminiferal propagules: a key feature for dispersal? Evidence from two shallow-water species
}

\author{
ELISABETH ALVE ${ }^{1} \&$ SUSAN T. GOLDSTEIN ${ }^{2}$ \\ ${ }^{1}$ Department of Geology, University of Oslo, P.O. Box 1047 Blindern, 0316 Oslo, Norway \\ ${ }^{2}$ Department of Geology, University of Georgia, Athens, Georgia 30602, USA
}

Understanding dispersal mechanisms in benthic formainifera has wide implications for explaining their geological and biological distribution in space and time, including evolutionary and genetic trends. Because they lack a planktonic larval stage (although a few have a meroplanktonic life stage), their mode of dispersal in the marine environment has been subject to much speculation, and a range of alternative mechanisms have been suggested (for a review, see Alve (1999) and further discussion in Hayward et al. (1999)).

In the present note, we suggest a mechanism which is more efficient and probably more widespread than most of those previously proposed. We hypothesize that many species produce 'propagules' (small juveniles, perhaps just the proloculus) released in large numbers following reproduction that may enter a resting stage. Propagules can be widely dispersed by normal physical processes (currents, sediment transport) and ultimately settle over a range of habitats and conditions. Growth and reproduction commence only in those individuals and species that reach a suitable environment. We have two lines of evidence from completely different shallow-water environments (Norwegian fjord and the Florida Keys, USA) that strongly support our hypothesis.

\section{Observations}

Surface sediments from a box core were collected at $60 \mathrm{~m}$ water depth in the inner part of Oslofjord 10 September 1999. Some of the sediment was processed immediately after collection, and the remaining bulk sample was transferred to a transparent container with ambient seawater, sealed, and placed on a window ledge until 30 March 2000. Those subsamples processed immediately after collection contained no live or dead Ammonia beccarii (Linné, 1758). However, by the end of March the sample on the window ledge was crowded with huge $(300-450 \mathrm{~m})$ individuals of this species. Exactly the same happened with a sample collected 23 February 2001 at $84 \mathrm{~m}$ and checked 4 September 2001. Sediment collected 13 December 2000 at $67 \mathrm{~m}$ water depth was gently homogenized, larger $(>1 \mathrm{~cm})$ metazoans were removed, $15 \mathrm{ml}$ of the sediment was transferred to transparent $40 \mathrm{ml}$ plastic containers, topped with ambient seawater and sealed with Nescofilm to avoid evaporation. Three sub-samples were processed immediately after collection, whereas the rest were left to sit on the window ledge. The immediately processed samples did not contain any live or dead $A$. beccarii ( $>63 \mathrm{~m}$ fraction), and the same was the case with samples processed 17 January, 31 January, and 15 February 2001. By 5 June, however, the small containers were crowded with big, live specimens of this species and some dead tests.

Individuals of Gromia oviformis Dujardin, 1835, were retrieved from sediments collected from a shallow seagrass bed on the seaward side of Little Duck Key, Florida, 12 December 2000. Specimens were isolated, fed with diatoms (Thalassiophysa hyalina (Greville, 1865)), sealed in a $60 \mathrm{ml}$ Nalgene jar with ambient seawater, and mailed to Oslo 14 March 2001. The jar was situated near a window at room temperature (about $20^{\circ} \mathrm{C}$ ) and consequently exposed to daylight. By the end of June, all individuals of $G$. oviformis were dead and had started decaying though the clear test was still intact. No living foraminifera were recorded under the microscope (Nikon SMZ 1000, magnification up to 120 times). On the 21 December 2001, numerous specimens of Bolivina sp. were present in the jar, and most specimens were clustered around (with their apertures facing) the Gromia remains. The majority had a completely orange colour and a few were bright red. Empty (dead) tests were also present. No other foraminifera were recorded.

All containers contained micro-algae, which kept the sealed cultures from going anoxic.

\section{Discussion}

The fact that neither live nor dead tests of Ammonia beccarii and no individuals of Bolivina sp. were observed before or after the two and three month's periods, respectively, but that they occurred in high abundance several months later, shows that they must have been present as propagules, probably a young, embryonic, juvenile stage, which responded when conditions became appropriate for their growth and reproduction. For A. beccarii, it can be argued that the size fraction $<63 \mu \mathrm{m}$ also should have been checked but the fact that no dead tests were present, strongly indicates that it did not live and reproduce at the sites of collection (i.e. at 60, 67, and $84 \mathrm{~m}$ water depth). This is not surprising, as $A$. beccarii is widely accepted as a shallow-water species (e.g. Goldstein \& Moodley, 1993). In the Oslofjord, it is primarily confined to water depths $<10 \mathrm{~m}$ where it is one of the predominant foraminiferal species; it is rare below $20 \mathrm{~m}$ and dead tests are only occasionally recorded at $>40$ m (Risdal, 1964; Alve \& Nagy, 1990). Conditions in the cultures, unlike those in the deeper water natural environments, allowed this foraminifer to thrive and reproduce.

Both species showed a lengthy delay in growth and reproduction following collection. For Ammonia beccarii, the sudden growth and reproduction (latter evidenced by presence of dead tests), was probably triggered by the spring bloom in certain 
micro-algae on which it could feed. This means that the original sediments, collected from well below the photic zone and subsequently exposed to daylight for months, must have contained propagules of both $A$. beccarii and micro-algae. For Bolivina sp., the propagules were probably present either associated with sediment particles in the apertural region of some Gromia specimens or inside the Gromia tests. Thick and ultrathin sections of Gromia from the Little Duck Key collections revealed living dinoflagellates and an unidentified protist alive in the cytoplasm. In addition, abundant stercomata have been well documented in G. oviformis (e.g. Hedley \& Bertaud, 1962). The presence of dead tests of Bolivina sp., indicate that some specimens had reproduced. Boltovskoy \& Lena (1969) suggested that the life cycle of small species probably is as short as one month, but extremely rapid reproduction rates, just a few hours after the gamonts leave the reproductive cyst, have been reported in very small taxa (Pawlowski \& Lee, 1992). Our Bolivina sp. is very small (length: $<200 \mu \mathrm{m}$ ), suggesting it probably has a short turnover rate. Still, as opposed to $A$. beccarii, it did not appear to reproduce in response to the algal spring bloom. Rather, Bolivina sp. seems to feed on the decaying Gromia remains and any associated microbiota, implying that specimens were in a resting stage until these became available.

Our results indicate that benthic foraminiferal propagules are able to become inactive or perhaps dormant for at least two to three months and subsequently start growing when the conditions become suitable. Additionally, although the life cycle in foraminifera is more varied than in virtually any other group of protists (Goldstein, 1999), there are no lines of evidence suggesting that there are differences in the kinds of life cycles adopted by shallow and deeper water species. This indicates that the resting stage recorded in the two reported shallow-water species, also may occur in deeper water species. The hypothesis presented here is that propagules, due to their tiny size, are easily released to the water masses, that they are able to go into a resting stage (i.e. stay alive until conditions are appropriate for growth and reproduction) and, consequently, are present in large numbers throughout the world's oceans, that they settle in a wide range of habitats, but that only those that settle in suitable environments start growing and reproducing. Consequently, we think that transport of propagules (as opposed to larger growth stages) is a significantly more common mechanism for dispersal over longer distances than previously appreciated. Transport of pelagic juveniles over a short distance (from littoral to adjacent tide-pool habitats) was suggested by Walker (1976). A predominant infaunal microhabitat, which is reported in some species, should not limit their ability to become dispersed in this way because the depth at which they occur in the sediment varies between environments and even with time at the same site (e.g. Kitazato \& Ohga, 1995). This implies that portions of otherwise infaunal populations may also occur in surface sediments. They may also get transported up from deeper layers by bioturbating organisms as suggested in Jorrisen (1999, fig. 10.1). This is further supported by experimental evidence showing transport of foraminifera sized quartz grains from $6 \mathrm{~cm}$ depth up to the surface sediment (Alve \& Skei, unpublished data).

It is a common view that benthic foraminifera are passively dispersed as growth stages or adult specimens either by water currents or by temporal attachment to, or other means of transport with, other organisms. Although such means of dispersion are likely to occur in a number of instances, the suggested mechanism, if correct, offers an explanation that is of a considerably more general character and applicable to all marine environments interconnected by seawater. This suggests that foraminifera may disperse quickly, thereby maintaining a geographically extensive gene pool, in spite of the absence of a planktonic stage in most species. If this resting stage is a characteristic feature in most benthic foraminifera, it explains a number of previously unanswered questions.

\section{ACKNOWLEDGEMENTS}

We thank Jere Lipps for helpful comments on the manuscript.

\section{Manuscript received 28 December 2001 Manuscript accepted 19 January 2002}

\section{REFERENCES}

Alve, E. 1999. Colonisation of new habitats by benthic foraminifera: a review. Earth-Science Reviews, 46: 167-185.

Alve, E. \& Nagy, J. 1990. Main features of foraminiferal distribution reflecting estuarine hydrography in Oslo Fjord. Marine Micropaleontology, 16: 181-206.

Boltovskoy, E. \& Lena, H. 1969. Seasonal occurrences, standing crop and production in benthic foraminifera of Puerto Deseado. Contributions from the Cushman Foundation for Foraminiferal Research, 20: 87-95.

Goldstein, S.T. 1999. Foraminifera: A biological overview. In Sen Gupta, B.K. (Ed.), Modern Foraminifera, 37-55. Kluwer, Dordrecht.

Goldstein, S.T. \& Moodley, L. 1993. Gametogenesis and the life cycle of the foraminifer Ammonia beccarii (Linné) forma tepida (Cushman). Journal of Foraminiferal Research, 23: 213-220.

Hayward, B.W., Grenfell, H.R., Reid, C.M. \& Hayward, K.A. 1999. Recent New Zealand shallow-water benthic foraminifera: Taxonomy, ecologic distribution, biogeography, and use in paleoenvironmental assessment. Institute of Geological \& Nuclear Sciences monograph, 21: $1-264$.

Hedley, R.H. \& Bertaud, W.S. 1962. Electron-microscopic observations of Gromia oviformis (Sarcodina). Journal of Protozoology, 9: 79-87.

Jorissen, F.J. 1999. Benthic foraminiferal microhabitats below the sediment-water interface. In Sen Gupta, B.K. (Ed.), Modern Foraminifera, 161-179. Kluwer, Dordrecht.

Kitazato, H. \& Ohga, T. 1995. Seasonal changes in deep-sea benthic foraminiferal populations: Results of long-term observations at Sagami Bay, Japan. In Sakai, H. \& Nozami, Y. (Eds), , Biogeochemical Processes and Ocean Flux in the Western Pacific, 331-342. Terra Scientific Publishing Company (TERRAPUB), Tokyo.

Pawlowski, J. \& Lee, J.J. 1992. The life-cycle of Rotaliella elatiana n.sp.: A tiny macroalgavorous foraminifer from the Gulf of Elat. Journal of Protozoology, 39: 131-143.

Risdal, D. 1964. Foraminiferfaunaenes relasjon til dybdeforholdene i Oslofjorden, med en diskusjon av de senkvartære foraminifersoner. Norges Geologiske Undersokelse, 226: 5-142.

Walker, D.A. 1976. An in situ investigation of life cycles of benthonic midlittoral foraminifera. Maritime Sediments Special Publication, 1: $51-59$. 